\title{
RELATIONS BETWEEN COMMUNICATION AND DEVELOPMENT OF FAMILY FARMERS
}

\section{ANA PAULA S. PONCHIO ${ }^{1}$, JULIETA T. A. DE OLIVEIRA ${ }^{2}$}

\begin{abstract}
This research investigates relations between communication and the development of family farmers from the Pontal do Paranapanema region (state of São Paulo), mainly in the municipality of Teodoro Sampaio. Family agriculture in this municipality is represented basically by beneficiaries the Agrarian Reform program. The main hypothesis is that communication contributes positively to the development of those family farmers. Thus, this study aimed to understand communication practices of these farmers and relate them with the development of their families. Quantitative and qualitative research methods were used. Development proxy is understood as the combination between the family living conditions and production. Among the main results, it was found that the effect of communication for "life and production conditions" increases as farmers at superior levels of "development" are analyzed; thus the main hypothesis should not be rejected for those farmers with higher development condition. For the others, communication did not have the same effect because many settled families are not focused on agricultural activities. The main suggestion is to improve ways for producers and professionals from public services related to them to access information.
\end{abstract}

KEYWORDS: access to information; dialogue; agrarian reform; Pontal do Paranapanema region.

\section{RELAÇÕES ENTRE COMUNICAÇÃO E DESENVOLVIMENTO DE AGRICULTORES FAMILIARES}

RESUMO: Esta pesquisa analisa as relações entre comunicação e desenvolvimento de agricultores familiares do Pontal do Paranapanema (SP), especificamente de Teodoro Sampaio. A agricultura familiar desse município é representada basicamente por assentados da reforma agrária. A hipótese principal é que a comunicação entre os familiares, bem como os representantes dos serviços públicos, é um dos fatores que contribuem para o desenvolvimento desses agricultores. Assim, o objetivo geral foi entender suas práticas de comunicação e relacioná-las com o desenvolvimento de suas famílias. Foram usados métodos quantitativos e qualitativos de pesquisa. Assumiu-se como proxy de desenvolvimento a combinação entre a condição de vida da família e a evolução de sua produção agropecuária. Entre os principais resultados, constatou-se que o efeito da comunicação em favor da "condição de vida e produção" aumenta conforme se analisam produtores nos estágios superiores de "desenvolvimento" e, dessa forma, a hipótese principal não pode ser rejeitada para parte dos produtores. Para os demais, a comunicação não teria tido o mesmo efeito porque muitas famílias assentadas não estão focadas na agropecuária - considerada na proxy de desenvolvimento. A principal recomendação é que sejam ampliadas as formas de acesso à informação, tanto dos produtores quanto dos profissionais do serviço público que os atendem.

PALAVRAS-CHAVE: acesso à informação, diálogo, reforma agrária; Pontal do Paranapanema.

\footnotetext{
${ }^{1}$ Jornalista, Doutora, Faculdade de Engenharia Agrícola, FEAGRI/UNICAMP. Campinas - SP. Fone: 11 2528 7226, apsp@usp.br.

${ }^{2}$ Enga Agrônoma, Doutora, Faculdade de Engenharia Agrícola, FEAGRI/UNICAMP. Campinas - SP.

Recebido pelo Conselho Editorial em: 6-12-2011

Aprovado pelo Conselho Editorial em: 2-8-2013
} 


\section{INTRODUCTION}

This research addresses the relationship between communication and development of family farmers. Communication may have a strategic role in the development process - broadly understood as improvement of living conditions - as it facilitates changes and approximation between people. However, the required change does not occur spontaneously. According to BARRANQUERO (2007), to promote communication transformative actions must be intentionally directed and systematically planned. Communication models aiming at the development should be based on the perspectives of the participating people, which are the ones that have the most to gain and lose with strategies based on horizontal communication (DEANE, 2007).

In a society with strong ties among its participants, communication tends to be processed in order to strengthen exchanges and approaches, and this relationship would further the "development". On the other hand, the challenge is to optimize (or use) the features of this communication (social process) in a society that is still building their relationships so that they function as a catalyst for improving the living conditions of these families.

This context can be found in areas of deployment of agrarian reform. Families with different backgrounds are installed in nearby areas and, in general, have the prospect of building a new territory, a process that occurs through successive negotiations, also with other actors in society. Under this empirical scope, daily practices of communication of the settled families in the Pontal do Paranapanema region were surveyed.

The main hypothesis of this research was that communication is one of the factors that influence positively the development of family farmers. It is believed that more intense communication habits acts as a stimulus to development. Given the difficulty in operationalizing the breadth of the concept of development in order to test this hypothesis by quantitative instruments, this research specifically evaluates the relationship between communication and "living conditions and agricultural production", assuming this combination as a proxy of development of families of family farming in the region. The specific objectives are: (a) verify whether, over the years, the community was being reinforced or if, instead, there were a tendency to individualization - which could be important for the effective conduct of public policies; and (b) identify whether there was any relationship between individual communication habits and the "development" of family farmers.

The theoretical framework was based, in particular, on the propositions of the Bolivian Luis Ramiro Beltrán Salmón, about the contributions of "Communication for Social Change", on the Indian economist Amartya Sen, who relates social development and individual freedoms, and on the Brazilian Maria de Nazareth Baudel Wanderley, regarding family farming and rural areas in Brazil.

Horizontal communication or for social change have as key elements the free and equal access to information, dialogue and participation, with interdependent functions (BELTRÁN, 2007). Thus, the communication would play an important role for the development, understood as a process of expanding the real freedoms that people have, and, therefore, it is necessary to "remove the sources of deprivation of liberty," such as poverty, lack of economic opportunities and negligence of public services (SEN, 2000).

In Brazil, discussions about rural development increased in the 1990s, stimulated by the strengthening of family agriculture (KAGEYAMA, 2008). Data not only from the 2006 Agricultural Census, but also from earlier works, show that family agriculture in Brazil represents between $70 \%$ and $90 \%$ of farms, occupying more than half of the staff allocated to agriculture (KAGEYAMA et al., 2010). To WANDERLEY (2009), the current agriculture is characterized by broad market integration and its opening to the modern way of life, which resets the internal workings of the family farm unit and its logic. Among the various types of modern farmers, agrarian reform settlers are a category. Family farming is also characterized by the multiplicity of 
both the processes that gave rise to settlements and the situation of families in these projects nowadays, which shows its diversity (WANDERLEY, 2009).

\section{MATERIAL AND METHODS}

\section{Characterization of the region}

The Pontal do Paranapamema is located in the extreme west of the state of São Paulo, bordering the states of Paraná and Mato Grosso do Sul. It is one of the less developed regions of the state and also home to more than half of all families settled in the state - i.e., is a land of active reconstruction of the territory (understood as the physical space where power relations among its various actors are projected). According to data from ITESP FOUNDATION (2011), 5,482 families have already been settled in the Pontal do Paranapanema - there are settlements in 14 of its 32 municipalities - from the 10,100 families statewide. Teodoro Sampaio, where this study was conducted, has 849 families settled - 29 from 2009 did not integrate the sample. The survey was conducted in $100 \%$ of settlements with more than two years of establishment, with a random sample of families.

The region's history is marked by the action of "explorers of the hinterlands", that, in the second half of the $19^{\text {th }}$ century, took ownership (through land-grabbing) of public vacant lands of the west of the state. In recent decades, the strong resistance against land-grabbing of land has resulted in the construction of new territories in the region from agrarian reform or regularization.

Although the city of Teodoro Sampaio is in the region that has more than half of the settlements in the state, the 2006 census showed that the 806 agricultural establishments classified as family farms $(80.3 \%$ of total) occupied only $16.6 \%$ of the area (16,538 hectares). The remaining 198 represent not family farms, with an area of 83,328 hectares (IBGE, 2009), which indicates the concentration of land in the region where land titles are questioned by the government.

Combining data from Lupa - Census Survey of Agricultural Production Units (SÃO PAULO, 2007/2008) with records from ITESP FOUNDATION (2011), both for the year of 2007, it was estimated that there were 919 family farms, of which 810 were settlements and 109 belonged to the traditional small farmers (not settled).

\section{Material and Methods: Collection procedures and data analysis}

The developed research was explanatory as to its purposes, also with characteristics of a descriptive study. Regarding to the means for data collection, guided interview (semi-structured) methods were employed, structured interviews (questionnaire) and non-participant observation, in an effort to combine quantitative and qualitative data.

Initially, this research focused on family farmers from the Pontal do Paranapanema, especially in the city of Teodoro Sampaio, which included, therefore, settlers and traditional small farmers. Field surveys began by guided interviews with representatives of entities directly related to these two groups of farmers: government agencies of technical assistance and rural extension, as Incra, Itesp Foundation, the Secretary of Agriculture and Supply of the State of São Paulo, the Department of Agriculture of Teodoro Sampaio and the Union of Rural Workers and Employees in this municipality. The interviews were conducted in April 2010, based on common script for all entities.

These interviews also helped in shaping the other side of data collection: the application of questionnaires to the farmers (respondents were the land owners or their spouses), which occurred in July 2010. Eighty-one settlers and 15 traditional small farmers were interviewed, the last ones discarded later for not fitting the legal requirements of family farmer. The proportional sample had statistical error of $10 \%$, calculated based on BARBETTA (2002).

Most interviews were conducted during visits to small farms (from settlements or not) randomly chosen, always seeking to reach homes far from each other. In one day of the survey, interviews were conducted downtown, aiming at observe the sociability between farmers from 
different settlements. The date was chosen because it was the "shopping day" for many of the families who had milk as main income.

In parallel, non-participant observations improved the field knowledge and have provided subsidies for the sample size, statistically subject to an error margin of $10 \%$, could be considered representative of the analyzed reality.

For the interpretation of guided interviews, the analysis of the semantic-pragmatic meaning of the conversation was adopted; in turn, the quantitative analysis was based on the dynamic Excel tool and also on regressions made through the statistical software Stata 9.0. In search of statistical arguments for checking the main hypothesis, two econometric models were specified. Thus, the variables were added in order to obtain a proxy for communication and another that expressed "development". However, the difficulty of representing the breadth of the concept of development through variables with quantitative content led to the development of a proxy based on the combination of the condition of family life and the evolution of its agricultural production, aspects which involve the notion of development, but does not restrict it. In this work, therefore, statistical analysis of the "development of families" refers merely to their conditions of life and evolution of rural production.

To carry out the statistical analyzes, these proxies were considered "indicators". The indicator of living conditions and production was based on the answers to two key questions that define it: one on the living conditions of the family and the other to the evolution of agricultural production, since the scope of this work is the family farming, that also in an environment of agrarian reform, have in your modus operandi the agricultural production as an essential part, as well as prescribing the guidelines of the Brazilian agrarian reform.

The evaluation of the condition of life of the family could be: very bad (zero in the indicator), bad (1), fair (2), good (3) and excellent (4). Regarding to production, if it had decreased, the ratio would be 1 , if equal, 3 , and, if increased, 6 . This encoding aimed to give equal weight to the two variables that compose the window - the sum of both is equal to 10 . This indicator represents the sum of the coefficients of the variables and ranges from 1 (very bad condition of life [0] and the reduction of agricultural production [1]) to 10 (excellent condition of life [4] and the increase in production [6]).

The different combinations of responses divided the respondents into three groups, which were called, by convention, development groups - although the limitations that the proxy provides for the concept of development are recognized. Thus, there would be groups of "impaired development", "partial development" and "full development".

With regard to communication, the indicator of daily communication showed 14 variables that could be related to the key elements of communication for social change. These variables were: related to access to information via formal means: (1) has TV, (2) radio, (3) uses the internet (regardless of location); b) related to dialogue and social participation: (4) usually attends to courses, (5) participates in an association/cooperative; (6) feel motivated to participate in collective activities, (7) get information with extension agents (includes mention of NGOs), (8) reports with producers/other agents (other than extension agents), (9) usually uses extension agents when needs to discuss something, take questions, (10) usually turns to other producers and/or family when needs to discuss something, (11) usually visits neighbors, (12) would like to have opportunities to talk more, (13) has means of transport (car and/or motorcycle), (14) has a telephone (mobile and/or landline) - the latter two are seen as means to facilitate social interactions. The variables have equal weights, being accounted one point for each positive response. Two variables resulting from interactions between two of the three development groups and their respective indicator of communication have also been proposed.

Multiple linear regressions, estimated by the least squares method, since it was necessary to control the effects of heteroscedasticity (HOFFMANN \& VIEIRA, 1987), were used. A model that 
has the indicator of daily communication as dependent variable was adjusted and other for the indicator of living conditions and production of settled families. The control variables are repeated in both models, since it is assumed that they have much influence on a dependent variable as in another. To avoid multicollinearity problem, the control variables were subjected to correlation analysis.

In the communication model, the indicator of living conditions and production was not included as it was considered that the effect of dependence is from the communication for the "development". The model included binary of the "partial development" and "full development" groups (they are not, therefore, indicators of these groups) in order to observe whether there are differences in the effect of "levels of development" on communication. In the model of "living condition and production" (development proxy), two interaction variables were created in order to analyze whether there are differences in the influence of the different communication groups ("impaired", "partial" and "full development") on the indicator of living conditions and production. Each binary representing the partial development and full development groups was multiplied by the indicator of communication, so that the resulting variable (interaction) assumed the value of the communication indicator when the binary was one and zero and when the binary was zero.

Below the indicator of daily communication model (Equation 1) and the indicator of living conditions and production of the settled families (Equation 2) are shown:

$$
y=\alpha+\sum_{i=1}^{8} \beta_{i} x_{i}+\sum_{i=1}^{2} \lambda_{i} w_{i}+\varepsilon_{i}
$$

where:

$\mathrm{y}_{=}$Communication indicator; $\mathrm{x}_{\mathrm{i}}=$ control variables;

$\mathrm{w}_{\mathrm{i}}=$ binary variable $(\mathrm{i}=1$ regarding to the partial development group, $\mathrm{i}=2$ to the full development group) (binary variables were created with value 1 for information related to a given group and zero to others); $\varepsilon_{i}=$ stochastic term.

Control variables $(x)$ were: respondent gender, time s/he lives in the lot, education of the respondent, how did his/her family received the land, agricultural income, income given by the government, income of works outside the lot and possibility of financing.

Bellow is the model of the indicator of living condition and production (Equation 2).

$$
Z=\alpha+\beta_{1} y+\sum_{i=1}^{8} \beta_{i} x_{i}+\sum_{i=1}^{2} \lambda_{i} \gamma_{i}+\varepsilon_{i}
$$

where:

$Z=$ indicator of living conditions and production; $Y=$ indicator of communication (sum of the ways used for communication); $x_{\mathrm{i}}=$ control variables (the same of the communication model); $\gamma=$ interaction of binary variables $(i=1$ regarding to the partial development group; $i=2$ regarding to the full development group) regarding to the communication indicator; $\varepsilon_{i}=$ stochastic term.

\section{RESULTS AND DISCUSSION}

The Pontal do Paranapanema has about 5,500 families who consume, work and build a new territory in that region that still displays low levels of development.

Of the 18 settlements of the sample, one was established in 1988, 14 between 1997 and 2000, and the other three in 2003. The period of greatest number of settlements, therefore, coincides with the phase in which the land occupations were more intense in the region (1995-1998). Thirty-seven women and 44 men (land owners or spouses) were interviewed, 18.5\% were aged 22-39 years old, $38.3 \%$ were 40-54 years old, 29.6\% were 55-65 years old, and 13,6\% were older than 65 . 
The maximum education of these people was the high school (11 years of schooling), level achieved by $21 \%$ of them; on the other hand, $17 \%$ were uneducated, but seven of them shared the decision on the lot with a spouse or child who knew how to read and write. "Elementary" and "middle school", complete and incomplete, represented $62 \%$ of the sample. These averages are below the calculated by the IBGE Census of 2000 for the city (Teodoro Sampaio), but are consistent with the research conducted by the Brazil's National Institute for Colonization and Agrarian Reform (INCRA, 2010), covering all 804,867 families settled in the country from 1985 to 2008 , which reported that $69.85 \%$ of the land owners had only middle school as education.

Of the 81 respondents, 59 ( $73 \%$ of the sample) were settled directly or received their lot from their parents or grandparents $\left(2^{\text {nd }}\right.$ generation) and $22(27 \%)$ had the right to the lot from the exchange or the criteria of the Itesp's No. 50 Order. Twelve percent were in the land for three years or more, $28.5 \%$ from four to nine years, $48 \%$ were 10 to 15 years and $11 \%$ for more than 15 years. The main source of information of these families was the producers/family, which can create a vicious circle because, predominantly, they were disadvantaged in access to information outside the group. The second main source was extension agents, which also reported lacking of information, as observed by TAVEIRA \& OLIVEIRA (2008).

As for the formal means to obtain information, only in one of the houses there was no television, and almost every house had also a satellite dish, which transmits the national TV programming instead of the regional. There was no radio in just seven of the 81 residences. None of the respondents used to buy or access free printed publications. However, when asked about a formal communication that dealt with issues related to family farms, 42 of them, including seven uneducated, would prefer a printed bulletin. The internet was still far from most of them - only 5 of the 81 reported using this mean of communication - although many are interested in having it.

As the income of these families, a research of OLIVEIRA \& ANDRADE (2011), in the same region, also found that only $6 \%$ lived with until one minimum wage/month - R $\$ 510.00$ at the time. A group with $38 \%$ of families was receiving one to two minimum wages and $33 \%$ had two to three minimum wages, almost $20 \%$ had income between $\mathrm{R} \$ 1,650.00$ and $\mathrm{R} \$ 3,700.00$. Only $7.5 \%$ of households depended solely on the income earned on the land, while another $10 \%$ did not have any land income. Of the 81 families interviewed, $62(77 \%)$ received some government benefit, and 29 $(36 \%)$ had income from work outside of the lot.

Among those who obtained some land income, dairy farming was the main activity for $90 \%$ of them, followed, by more than half the cases, by the plantation of eucalyptus as a second income. Agricultural production increased in $46 \%$ of the lots in comparison with the second year of the settlement and declined in $18.5 \%$. Six respondents $(7 \%)$ were in the lot for two years or less and, by convention, are placed in the stable production group.

Comparing the living condition of the families prior to the arrival in the settlement, only $6 \%$ rated it as worse, 5\% answered it was equal and $89 \%$ said that it was better or much better, an indication of the benefits of agrarian reform for much of beneficiaries also found by INCRA (2010) in the statement of the settlers about the improvements in living conditions and changes in equity for families after land access.

Regarding the living conditions of the family at the time of the survey, one respondent considered it as very bad and two $(2.5 \%)$, as bad; for 23 respondents $(28 \%)$, the situation was fair, $51 \%$ considered it as good and $17 \%$, as very good (55 families in the latter two). This assessment reinforced FERRANTE \& BERGAMASCO (1995) that showed that many benefits are absorbed by the settlers after the implementation of the settlement: improvement in nutrition, health, children's education and housing.

Taking into account the groups of families defined by the indicator of living condition and production, the "full development" group was composed of 26 producers (living conditions are 
good or excellent, and production increased). On the other hand, for the "impaired development" group, there were eight producers (very bad, bad or fair life, and decreased production).

The remaining 47 settlers were allocated to the "partial development" group. Twenty-nine people (62\%) of this group considered the condition of his/her family life as good or great, but its agricultural production had remained the same or had decreased, and 18 other people (38\%) indicated poor ( 1 case) or fair living condition, with stable or increasing production. By analyzing the subgroups of this category, there is a positive effect of education on production, but there is also the opposite regarding their satisfaction with living conditions in the settlement.

The "impaired development" group is formed by producers with higher education than those from the "full development" group. However, it can be seen that the focus of those from the impaired development group would be activities outside the lot - six of these families have the main income from other activities. It is inferred that the relationship between higher education and reduction of agricultural production is established as the extra years of study, precisely, would provide alternatives considered more attractive than to work on the lot.

As for the time the family is on the lot, no significant difference was found between the categories. When analyzing the income, it is clear that the amount by different sources was much higher for the "full development" group than for the "impaired development" one.

In the analysis of variables related to communication habits, the "impaired development" group interacted socially less than others, or otherwise, the "more developed" producers have more active habits of communication, signaling that the hypothesis that communication contributes to improvement of living conditions and production should not be rejected.

The model that had as dependent variable the indicator of daily communication reiterates this analysis (Table 1). Its results indicate that the level of living conditions and production of the families has a positive effect on communication, confirming that the "more developed the family", the more it communicates, according to the criteria used, thus establishing a virtuous circle. This was evidenced when considering the differences between the "full" and "partial development" groups. The coefficient of the variable binary of "partial development" (0.6971) was positive but not significant. On the other hand, the binary coefficient of "full development" (1.7494) was positive and significant at the significance level of $5 \%$. The variables education, access to financing and way of obtainment of the land had positive and statistically significant coefficients at the level of $0.006,0.018$ and 0.059 of probability, respectively.

TABLE 1. Estimate of the function of the indicator of daily communication.

\begin{tabular}{lcc}
\hline Communication Ind. & Coefficient & T test \\
\hline Gender & 0.195 & 0.49 \\
Time in land & -0.049 & -1.11 \\
Education & $0.1652^{* * *}$ & 2.83 \\
Way of obtainment of the land & $0.9826^{*}$ & 1.92 \\
Agricultural income & 0.0002 & 0.3 \\
Government given income & 0.0000 & 0.12 \\
Income obtained outside of lot & -0.00026 & -0.68 \\
Access to financing & $1.0797 * *$ & 2.43 \\
Partial Develop. Group & 0.6971 & 1.09 \\
Full Develop. Group & $1.7494 * *$ & 2.25 \\
Constant & 6.3127 & 6.5 \\
\hline
\end{tabular}

Source: Study data (2010). * Significance level: 10\%; ** Significance level: 5\%; *** Significance level: $1 \%$.

Regarding education, the result supports the perception that people with more education tend to seek more information and also to express their ideas more intensely. This situation can also be 
related with the answers of accessing to credit. It can be seen that people who have higher education and communicate more end up having better financial opportunities, either in the forms of trading, and the ability to provision resources. Taking out loans, in turn, tends to stimulate investment in agricultural production, which contribute to the development of families in the perspective taken reiterating the positive effect of communication for the "development". According to HOFFMANN \& NEY (2004) the low level of education of the majority of people employed in agriculture is a major obstacle to improving the quality of life in the field, because it compromises the increase in labor productivity, wage growth and, therefore, income, which contributes to the persistence of the problems of rural poverty.

By pointing positively the way the land was obtained, regression reports that those who were settled early in the project or those who received the lot from their parents/grandparents had more intense communication habits than those who succeeded by the criteria of Itesp's No. 50 Order and/or by exchange. When corroborating this model result, it is found that the average of the indicator of communication of "original settlers $/ 2^{\text {nd }}$ generation" was 9.1 , while the average of the other group was 8.4. This may relate to the construction of more effective links between those who have been together since the period of demand for land among others who came later.

In turn, the results of the adjusted model for indicator of living conditions and production of the settled families showed that the variables "communication of the full development group" and "communication of the partial development group" had positive and statistically significant coefficient with probability of less than 0.001 . The indicator of communication (which represents the "communication of the impaired development group", since communication of each of the other two groups are expressed separately), was also significant, but with a negative coefficient (Table 2).

TABLE 2. Estimate of the function of the indicator of living conditions and production.

\begin{tabular}{lcc}
\hline Ind. of Living Cond. \& Prod. & Coefficient & T test \\
\hline Communication indicator & $-0.5215^{* * *}$ & -4.98 \\
Gender & -0.2666 & -1.06 \\
Time in land & $0.0635^{* *}$ & 2.53 \\
Education & $0.06865^{*}$ & 1.95 \\
Way of obtainment of the land & $-0.7328^{* *}$ & -2.23 \\
Agricultural income & 0.0004 & 1.20 \\
Government given income & 0.0001 & 0.66 \\
Income obtained outside of lot & -0.0001 & -0.42 \\
Access to financing & 0.0395 & 0.14 \\
Partial Develop. Group & $0.4026 * * *$ & 7.68 \\
Full Develop. Group & $0.7393^{* * *}$ & 13.54 \\
Constant & 6.4974 & 7.25 \\
\hline Source: Study data (2010) * Significance level: $10 \% * * *$ Significance level: 5\%:*** Significance level: $1 \%$ &
\end{tabular}

Source: Study data (2010). * Significance level: 10\%; ** Significance level: 5\%;*** Significance level: $1 \%$.

Based on these results, the hypothesis that communication leads to improved living conditions and production cannot be rejected for the "most developed" group (coefficient of 0.7393; the coefficient of the "communication of the partial development group" variable becomes negative when the indicator of communication coefficient, -0.52156 , is subtracted from it, which value is 0.40263). For the others, the same statistical result was not found. However, the negative effect of the "communication of the partial development group" variable is much smaller than the effect of "communication of the impaired development group" on the indicator of living conditions and production, that is, the effect of the communication in favor of "living conditions and production" increases as producers are analyzed in "higher stages of development".

Thus, it can be seen that, for those who are satisfied with the condition of life and has increased production, reinforcements in communication tend to reflect positively on their 
"development". For the less favorable group, it is understood that the communication has not worked as part of the stimulus for what is being considered as "development" because of the emphasis on the development of agricultural production. Six of these eight families obtained the main income from working outside their lands. Therefore, the statistical outcome does not invalidate the role of communication for this group, but rather the centrality that was given to agricultural development in the proxy - supported, in turn, the content of public policies and specialised bibliography about rural development.

This regression results also show that the time in the lot coefficient was statistically significant at the 0.014 of probability, as verified for the coefficients of education and obtainment of the land, at a level of 0.055 and 0.029 , respectively. The latter, however, was negative. The variable of obtainment of the land is positive when analyzing the communication indicator, but negative regarding this other indicator. That means that "original settlers $/ 2^{\text {nd }}$ generation" have more intense communication habits, but the evolution of production was more positive in the other group.

The time in the lot (with a positive sign) is also a statistic indicative that "living conditions and production" of families require a "maturation period", to obtain advances in production and to strengthen relationships so they are satisfied with their living conditions. In evaluating professional extension, as the family situation improves, producers tend to work more by themselves than to work with others. This position was also noted during the questionnaires and showed the difference between "work collectively" and "social interaction". Many who were more engaged in the production in the land reported negative comments about "working together". On the other hand, individually, those producers were active as chatting with extension agents, farmers, and people from other sectors and participate in courses, for example. This profile could be taken into account in public policies (BRASIL, 2004) that require the producer to participate in the association to have access to resources, which ends up generating, in many cases, only formal entities.

As witnessed and also stated by respondents, interactions occur both in rural and in urban environment. Especially in the "shopping day", when usually they go to the city accompanied by the whole family, producers of various settlements meet, talk, have lunch together, spend time in the plaza, banks and shops. This dynamic, strengthened by the previously presented, leads to the conclusion that the hypothesis that has advanced in the construction of citizenship cannot be rejected.

The relationship network generated by the settlers, some interacting more than others, but without noting any isolation level, includes public extension agents, union representatives and also people from other sectors of society, as heard in interviews and observed in the field. Representatives of the five entities reported they are invited to parties that take place in the settlements, including some of a personal nature, such as birthday celebrations.

When asked about the profile of the settlers of Teodoro Sampaio, the representatives of the institutions highlighted the prevalence of people who manifest, ask, and seek their rights, regardless of their formal education. According to respondents, the majority speaks of policy, discusses and is not afraid to give a different point of view when talking to a technician. Back to the relationships between individual freedoms and social development proposed by SEN (2000), it is understood that access to information and the practice of dialogue in the context in question can be considered "enabling conditions" that favor individual accomplishments and social development.

\section{CONCLUSIONS}

Thousands of families, with or without previous ties, have built a new territory in the Pontal do Paranapanema region. The departure of some people and arrival of new occupants of the lots make the first stages of the socialization process coexist with those more mature, of consolidation of relationships. In this organic system are distinct habits of social interactions and also levels of development. 
It was concluded that there may be contributions of communication from different perspectives of development that those families will assume - and not only in the agricultural approach adopted in this study. It was noted that there are "thirst" for information and great interest in social interaction. There is already a network of communication that fosters consistent exchanges among the various actors - which makes possible the contribution of communication - but certainly the quality of these interactions could be better especially with more access to information.

In daily communication were found needs of these families as for the three elements of the theory of communication for social change - access, dialogue and social participation. Access to information may be considered precarious and opportunities for dialogue and participation could also be expanded. Extension agents also state extension needs in the process to be informed, even on issues that they assist.

When talking about ways to increase access to communication, no one thinks of actions that treat producers as mere recipients, apart from interactions, but on the contrary. There are planned initiatives that link access and dialogue.

Finally, it is important to remember that "development" was analyzed by statistical models based on an indicator that has half its weight linked to agricultural production. But diversification of sources of household income has grown and contributed to their living conditions.

Although this research was limited to a representative region of the country, it is expected that this effort draw attention to the potential that communication have to help people, by themselves, to optimize the interactions that give them better living conditions, personal empowerment, social and economic advances desired for agriproduction systems.

\section{REFERENCES}

BARBETTA, P.A. Estatística aplicada às ciências sociais. 5. ed. Florianópolis: Editora da UFSC, 2002. $340 \mathrm{p}$.

BARRANQUERO, A. Concepto, instrumentos y desafíos de la edu-comunicación para el cambio social. Comunicar, Huelva, v. 15, n. 29, p. 115-120, 2007. Disponível em:

<http://redalyc.uaemex.mx/src/inicio/ Acesso em: 27 abr. 2011.

BELTRÁN, S.L.R. El pensamiento latinoamericano sobre comunicación democrática. In: TENDENCIAS'2007 - Medios de Comunicación: El Escenario Iberoamericano. Colección Fundación Telefónica, 2007. p. 275-289. Disponível em: <http://www.infoamerica.org/primera /anuario_medios.pdf>. Acesso em: 19 jan. 2011.

BRASIL. Ministério do Desenvolvimento Agrário. Política Nacional de Assistência Técnica e Extensão Rural. Brasília: MDA, 2004. 22 p. Disponível em: <www.mda.gov. br/ portal/saf/arquivos/view/ater/Pnater.pdf > Acesso em: 20 jan. 2010.

DEANE, J. El contexto de la comunicación para el desarrollo. In: FAO/ONU (Org.). Comunicación y desarrollo sostenible: selección de artículos de la 9na mesa redonda de las Naciones Unidas sobre comunicación para el desarrollo. Roma: FAO/ONU, 2007. p. 43-63. Disponível em:

<http://www.fao.org/docrep/010/a1476s/a1476s00.htm>. Acesso em: 8 jan. 2009.

FERRANTE, V. L. S. B. e BERGAMASCO, S. M. P. P. Censo de assentamentos rurais do Estado de São Paulo: análise e avaliação dos projetos de reforma agrária e assentamentos do Estado de São Paulo. Araraquara : Multicamp/Unesp; 1995. 183p.

FUNDAÇÃO ITESP. Fundação Instituto de Terras do Estado de São Paulo. Assentamentos: situação quanto à localização municipal, 2011. Disponível em:

<http://www.itesp.sp.gov.br/br/info/acoes/ assentamentos.aspx>. Acesso em: 15 mar. 2011.

HOFFMANN, R.; VIEIRA, S. Análise de regressão: uma introdução à econometria: 2. ed. São Paulo: Hucitec, 1987. 379 p. 
HOFFMANN, R.; NEY, M. G. Desigualdade, escolaridade e rendimentos na agricultura, indústria e serviços, de 1992 a 2002. In: CONGRESSO BRASILEIRO DE ECONOMIA E SOCIOLOGIA RURAL, 42., 2004, Cuiabá. Anais... Cuiabá: Universidade Federal do Mato Grosso; Embrapa Florestas, 2004, 28p. CD-ROM.

IBGE. Instituto Brasileiro de Geografia e Estatística. Censo Agropecuário 2006. Rio de Janeiro, 2009. Disponível em: <http://www.ibge.gov.br/home/estatistica/economia /agropecuaria/censoagro/brasil_2006/Brasil_censoagro2006.pdf>. Acesso em: 20 abr. 2011.

INCRA. Instituto Nacional de Colonização e Reforma Agrária. Pesquisa qualidade de vida nos assentamentos. Brasília : INCRA. Disponível em: <http://www.incra.gov.br/index.php/reformaagraria-2/questao-agraria/numeros-da-reforma-agraria/file/1152-pesquisa-qualidade-de-vida-nosassentamentos-2010>. Acesso em: 12 jun 2012.

KAGEYAMA, A. A. Desenvolvimento rural: conceitos e aplicação ao caso brasileiro. Porto Alegre: UFRGS Editora, 2008. 229 p.

KAGEYAMA, A.; BERGAMASCO, S.M.P.P.; OLIVEIRA, J.T.A. de. Caracterização dos estabelecimentos de assentados no censo agropecuário de 2006. Revista Retratos de Assentamentos, Araraquara, n. 13, p. 31-74, 2010.

OLIVEIRA, J. T. A.; ANDRADE, M.R. de O. Juventude e projetos de vida: desafios e perspectivas para a agricultura familiar de assentamentos paulistas. In: BERGAMASCO, S.M.P.P.; OLIVEIRA, J.T. A. de; ESQUERDO, V.F de S. (Org.). Assentamentos rurais no século XXI: temas recorrentes. Campinas: INCRA, 2011. v. 1, p. 341-364.

SÃO PAULO (Estado). Secretaria de Agricultura e Abastecimento. Coordenadoria de Assistência Técnica Integral. Instituto de Economia Agrícola. Levantamento Censitário de Unidades de Produção Agrícola do Estado de São Paulo - LUPA 2007/08. São Paulo: SAA/CATI/IEA, 2008. Disponível em: <http://www.cati.sp.gov.br/projetolupa>. Acesso em: 11 jun. 2011.

SEN, A. Desenvolvimento como liberdade. Tradução de Laura Teixeira Motta. São Paulo: Companhia das Letras, 2000. 175 p.

TAVEIRA, L.R.S.; OLIVEIRA, J.T.A. de. A extensão rural na perspectiva de agricultores assentados do Pontal do Paranapanema - SP. Revista de Economia e Sociologia Rural, Brasília, v. 46, p. 9-30, 2008.

WANDERLEY, M. N. B. O mundo rural como um espaço de vida: reflexões sobre a propriedade da terra, agricultura familiar e ruralidade. Porto Alegre: Editora da UFRGS, 2009. 330 p. 